The University of Maine

DigitalCommons@UMaine

Publications

Senator George J. Mitchell Center for Sustainability

Solutions

$7-2013$

\title{
Land Conservation in the Northeastern United States: An Assessment of Historic Trends and Current Conditions
}

\author{
Robert J. Lilieholm \\ University of Maine, robert.lilieholm@maine.edu \\ Spencer R. Meyer \\ University of Maine \\ Michelle L. Johnson \\ University of Maine \\ Christopher S. Cronan \\ University of Maine
}

Follow this and additional works at: https://digitalcommons.library.umaine.edu/ mitchellcenter_pubs

Part of the Environmental Law Commons, Natural Resources and Conservation Commons, and the Natural Resources Management and Policy Commons

\section{Repository Citation}

Lilieholm, Robert J.; Meyer, Spencer R.; Johnson, Michelle L.; and Cronan, Christopher S., "Land Conservation in the Northeastern United States: An Assessment of Historic Trends and Current Conditions" (2013). Publications. 97.

https://digitalcommons.library.umaine.edu/mitchellcenter_pubs/97 


\section{Land Conservation in the Northeastern United States: An Assessment of Historic Trends and Current Conditions}

Robert J. Lilieholm ${ }^{\mathrm{a}}$, Spencer R. Meyer ${ }^{\mathrm{b}}$, Michelle L. Johnson ${ }^{\mathrm{a}}$ and Christopher S. Cronan ${ }^{\mathrm{c}}$

${ }^{a}$ School of Forest Resources at the University of Maine in Orono, Maine

b Center for Research on Sustainable Forests at the University of Maine in Orono, Maine

c School of Biology and Ecology at the University of Maine in Orono, Maine 
Developed and developing nations around the world are struggling to balance human population pressures and development impacts with societal needs for landscape-level protection of important ecosystems and the services they provide. In the northeastern United States—one of the most densely populated regions of North America—-20\% of the land area is in conserved land status, much of which has been protected over the last quarter century. These gains have been achieved across a largely privately owned landscape experiencing rapid population growth and associated development using approaches and tools that have steadily evolved to address both changing landscapes as well as the public values that drive land conservation. It is this innovative adaptability and resilience that offer promise for conservation efforts worldwide.

The northeastern United States—composed of New York and the New England states of Maine, New Hampshire, Vermont, Massachusetts, Connecticut, and Rhode Island—contains a relatively small percentage of public land holdings, a high proportion of private land ownership (roughly 85\%), and a land-use pattern that is dominated by second-growth forest cover that dates to the aftermath of earlier periods of widespread farming and logging. It is also a region that has witnessed more than three centuries of diverse conservation efforts aimed at protecting treasured places for public use within a matrix of private ownership.

Despite a deep-rooted regional conservation ethic, local tensions and conflicts have arisen repeatedly over the balance between private development rights and public needs. Today, the northeastern United States contains a mosaic of developed and undeveloped lands that reflects the cumulative impacts of historical vacillations of land-use activities, development pressures, socioeconomic influences, expansion of transportation networks, and non-uniform state and local regulatory frameworks. Yet evidence of a strong conservation ethic is still very apparent. Even though ongoing processes of 
population growth and economic expansion have continued to transform open space and agricultural property into developed land uses, there has been a remarkable counterbalancing expansion of public and private land conservation activities aimed at protecting biodiversity, scenic values, ecosystem services, recreational opportunities, and unique natural areas in the remaining undeveloped land base. Because both development and conservation efforts in the region have occurred incrementally at multiple scales across a wide variety of jurisdictions, it is not readily apparent how overall landscape conditions have been affected by the aggregate impacts of these cumulative land-use decisions.

As planners and decision makers look to the future and increasingly think strategically about balancing land conservation and economic development activities, it will be important to (1) have a clear understanding of the current status, extent, and landscape patterns of conserved lands across the region; (2) know what kinds of values and conditions are represented in the conserved parcels; and (3) account for the dominant processes and criteria driving conservation activities across the different states of the Northeast. Insights from these types of spatial analyses and assessments can then provide a basis for improved land-use decisions aimed at promoting sustainable social and ecological communities.

In this article, we describe the evolution of land conservation efforts and outcomes in the Northeast, examine major drivers of landscape change, and review key conservation tools that have been used to protect public values at the local and landscape levels. We then assess the current status of land conservation, and draw lessons for other regions facing conservation challenges across mixedownership landscapes under varying development and land-use pressures. Finally, we explore new and emerging trends in the factors driving land development and conservation activities in an effort to assess the challenges that lie ahead. 


\section{Emergence of Land Conservation in the Northeast}

\section{Settlement and Expansion}

European settlement began in New England in the early 1600s. Over the next four centuries, settlement by colonists transformed the region—and much of the continent—from forest to farms, villages, and industrialized urban centers. Along the way, the region's indigenous tribes-Wabanaki, Passamaquoddy, Penobscot, Micmac, Mohegan, Narragansett, and Wampanoag-were either decimated by European diseases or were otherwise pushed to the margins of the developing land base.

The Northeast industrialized early, driven by abundant natural resources, growing populations, and ready power supplied by the region's seemingly endless forests and waterways. Maritime links opened trade with the rest of the world, and exports of fish and timber soon followed, along with the depletion of these renewable stocks. Following the American Civil War of 1861-1865, agriculture declined across the region as canals and railroads opened markets for more productive farmlands in the Ohio Valley and beyond. This exodus heralded the return of the region's forests - the dominant landscape feature that defines the Northeast to this day_as abandoned farms and pastures succumbed to newly regenerated forest. While the landscape is predominantly forested today, only about $0.2 \%$, or 53,000 acres (21,457 hectares or ha), of old-growth forests remain.

\section{The Rise of the Conservation Movement}

The roots of a New England conservation legacy can be traced back to the year 1634 at Boston 
Commons, where for the first time in the English-speaking world, people voted in favor of selftaxation in order to raise funds for the acquisition of public open space. Over the next two centuries massive changes swept across the landscape as farming expanded, forests were harvested, and an emerging technological revolution gained momentum. The accelerating pace of change soon spawned the impassioned writings of conservation luminaries such as Henry David Thoreau, Ralph Waldo Emerson, and George Perkins Marsh. These authors, along with Thomas Cole and other artists of the Hudson River School, provided the regional literary and artistic inspiration for a transformation of public attitudes toward wilderness that was articulated by such prominent conservation leaders as John Muir, Theodore Roosevelt, and John D. Rockefeller.

By the late 1800s, Progressive-Era conservationists elevated resource protection at both state and federal levels, which contributed to the passage of the Forest Reserves Act in 1891, establishment of Adirondack State Park in New York in 1892, and enactment of the U.S. Forest Service's Organic Act in 1897. In 1890, The Trustees of Reservations formed in Boston with a mission to acquire lands in their natural condition for the American public to enjoy. This was the world's first land trust—an organization with the legal ability to maintain ownership of property for the benefit of another party. Early on, land conservation in the Northeast was realized through fee-simple acquisition resulting from a mix of philanthropic donations, federal funding, and private financing. In Maine, Baxter State Park resulted from an individual gift from Governor Percival Baxter, whereas the Green Mountain and White Mountain National Forests in Vermont and New Hampshire originated through the federal Weeks Act of 1911. More recently, land and conservation easement acquisition funds have been provided through the federal Land and Water Conservation Fund of 1964.

Conservation easements are voluntary, legally binding agreements that sever specific rights from the land and typically are intended to endure in perpetuity. Easements are less costly than outright 
acquisition and can be tailored to protect a wide range of values and resources, including open space, wildlife habitat, watersheds, scenic vistas, historic lands and structures, and recreational lands. In virtually every state, conservation easements must be created for a purpose that benefits the public, and conveys to and is held by one or more governmental or nongovernmental organizations (e.g., a land trust) to be administered on behalf of the public. By leaving the easement-encumbered land in private ownership, owners retain many uses of the property while ensuring future protection. Despite the expectation of these benefits, there remains some confusion regarding what it means to protect land "in perpetuity" with a conservation easement—-that is, how permanent the easements actually are, and whether and how such instruments can be modified or terminated to, for example, respond to changing conditions.

Sidebar

\section{Conservation Innovation Around the Globe}

Land and biodiversity conservation efforts in New England, over the past four centuries, have both inspired and been inspired by initiatives in other nations around the globe. The creators of the Boston Common in 1634 drew upon older precedents set by feudally established, agriculturally oriented commons in England. Over succeeding decades and centuries, the democratic example set in New England then helped to advance the transformation of English society, and English land-use practices-including the establishment of parks and open spaces for the use by all of the people.

Early national parks established in the western United States in the last half of the nineteenth century, with key precedents set at Yosemite and Yellowstone, and then in 1916 at Acadia National Park in 
New England, have in turn been emulated by nearly 100 nations around the world in the succeeding 100 years. Similarly, the regional land trust movement born in Massachusetts in 1891 is now proliferating from Chile to Australia, Germany, and beyond. And, as demonstrated by the passionate engagement of the global membership of the International Union for the Conservation of Nature (IUCN), experts and concerned citizens in 160 nations are, in the twenty-first century, sharing ideas and inspiration to try to address the massive and daunting threats to biodiversity and its habitat. These threats, including global climate change, landscape fragmentation, and the rapid spread of invasive species, are largely indifferent to regional jurisdictions or national boundaries.

Just as these threats are globalizing at an increasingly rapid pace, so are some of the most promising present-day conservation innovations. Among these is the emerging practice of large landscape conservation, as exemplified by the work of the Wildlands and Woodlands Initiative in New England, and the binational Crown of the Continent efforts ongoing across an international border in Montana in the United States, and Alberta and British Columbia in Canada. Large landscape initiatives are today being successfully established in such disparate places as the cross-boundary corridor between the nations of Turkey and Georgia, the Canadian Boreal Forest, and the Phoenix Islands in the South Pacific. Even more expansive cross-sectoral, cross-jurisdictional, and broadly diverse efforts are now being envisioned from the Serengeti to Antarctica and the Arctic Circle.

—James N. Levitt, Director, Program on Conservation Innovation, Harvard Forest, Harvard University, and Fellow, Department of Planning and Urban Form, Lincoln Institute of Land Policy

\section{Conservation Finance}

In 1980, Congress granted favorable tax treatment to landowners who donate conservation easements as 
charitable gifts to government entities or charitable organizations for one or more of the four broad conservation purposes enumerated in the Internal Revenue Code (i.e., protection of open space, habitat, historic land areas or structures, or recreational lands). Then, in 1981, the Uniform Conservation Easement Act (UCEA) was approved, providing a model “enabling” statute for the states. Partly in response to these developments, the Northeast saw a proliferation of nonprofit land trusts at the local, state, and national levels, as well as an increase in the use of conservation easements. From 1981 to 2010, the number of land trusts increased from 164 to 500 across the region, and Massachusetts gained recognition for having the most land trusts in the region (159), a number that is second in the United States only to California, which has 197. In Maine, 88 land trust organizations helped to orchestrate the largest number of acres protected by easements of any state.

Beginning in the late 1980s, state bond initiatives became a popular funding source for a growing array of land conservation initiatives nationwide. In the Northeast, many such initiatives were brokered by groups such as The Nature Conservancy, the Trust for Public Land, and the Forest Society of Maine, working in concert with local land trusts and with funding support through the federal Forest Legacy Program. In the 1990s, these initiatives extended to the municipal level, particularly in and around rapidly developing areas such as Boston and the New York Metropolitan mega-region. From 1998 to 2005, almost $\$ 2.5$ billion in public bond investments was raised to fund land conservation in New England and New York. The key factors that have been identified to account for this widespread voter support for conservation funding in the Northeast include recognition of growing pressures from population growth and sprawling development, and active engagement of a highly educated and environmentally conscious citizenry. 
Today, conserved lands in the Northeast represent the culmination of over 100 years of conservation policy and land protection activities. In an effort to trace a timeline showing the temporal evolution of these lands, a spatial database of conserved parcels was assembled for three states with the most complete chronological data for dates of parcel protection—Vermont, New Hampshire, and Maine. Figure 1 traces the cumulative number of acres protected by different conservation strategies in that northern region, beginning in the early 1800s. The steady rise in public protection—reflecting milestones such as the creation of the White Mountain and Green Mountain National Forests in the early 1900s—is apparent through the 1980s.

Beginning in the 1990s, the time series shows the influence of the large areas that were conserved in northern Maine, New Hampshire, and Vermont as the forest products industry divested millions of acres of timberlands. Many of these lands were acquired by investment interests, including pension funds and real estate investment trusts, and these transactions created unprecedented opportunities to protect large tracts of private timberland from development. Conservation interests took full advantage of this transition and partnered with national, state, and local land trusts and forest products companies to keep working forest lands in production through large-scale conservation easements. Although prior to 2000 the average easement size in Maine was just 145 acres (59 ha), by 2010 it had risen nearly 10-fold to 1,160 acres (469 ha).

While much of the gain in this period was through these easements, some environmental nongovernmental organizations (ENGOs), including land trusts, purchased large tracts outright. In 1998, The Nature Conservancy purchased a 185,000-acre (74,867-ha) swath of forest along the St. John River in northern Maine, most of which they now manage for timber with the balance left as ecological reserves. Similarly, in 2003, the Appalachian Mountain Club, the nation's oldest recreation 
and conservation organization, purchased 37,000 acres (14,973 ha) of former industrial timberland to manage for recreation, conservation, and timber.

Since the 1980s, these initiatives and countless others have contributed to a doubling of the amount of protected land in Vermont, New Hampshire, and Maine. For these three states, the innovative mix of public/private partnerships and ENGO initiatives accomplished in just two decades a set of conservation goals comparable to what had been achieved by mostly public conservation efforts during the entire preceding century.

\section{The Need to Assess Conservation Outcomes}

One of the objectives of our assessment was to evaluate the current status of conservation lands in the Northeast region and to determine what kinds of conservation assets and values have been protected. The current portfolio of conserved and protected lands in the Northeast reflects more than a century of evolving institutional drivers (e.g., public versus private efforts, or changing policies at federal, state, or local levels) and overarching conservation goals (ranging from protection of watersheds, wildlife, or timberlands, to sustaining ecosystem functions and services). Given that historical context during a period characterized by dramatic socioeconomic and cultural changes, it is appropriate to ask how effective and successful conservation efforts have been across the region.

Assessing conservation outcomes is a necessary, but often neglected, part of the overall process of protecting natural resources. A common means of evaluating outcomes is to examine how well conservation goals are represented in the conserved land portfolio. Goals or targets may include vegetation types, landscape characteristics, or landscape metrics representing how likely conserved 
lands are to function as networks for sustaining plant and animal populations and fostering migration and gene flow—especially under various climate change scenarios. It is important to note that while goals may vary, the outcomes are often complementary, as evidenced by efforts to conserve ecosystem functions such as watershed protection, while providing economic benefits and employment opportunities from working forests and agricultural lands. Previous investigators have noted that the assessment process provides a basis for informed strategic conservation planning, and can identify and target underrepresented ecosystems, ecosystem services, and public values for future protection.

Conserved Lands in the Northeast Today

\section{Area and Configuration}

As of 2010, conserved lands constituted nearly $19.5 \%$ of the entire seven-state region, with a total of more than 14 million acres (5.7 million ha) in some form of protected status (Table 1 and Figure 2). On a statewide basis, conserved land areas ranged from a minimum of $16 \%$ of total land area in Connecticut, to a maximum of 29\% in New Hampshire. New York, the largest state in the region, had more conserved land than any other northeastern state, with a total of 5.7 million acres (2.3 million ha). For the entire region, per-capita land area was estimated at 2.4 acres ( $1 \mathrm{ha})$ per person, whereas conservation land area was 0.4 acres $(0.2 \mathrm{ha})$ per person.

In total, 9.3 million acres (3.7 million ha) are protected under public ownership in the northeastern United States, another 3.5 million acres (1.4 million ha) are held as private lands under protective easements, 1.2 million acres ( 0.5 million ha) are registered with nonprofit ownerships, and the remaining 
conservation lands are listed as "other" (0.2 million acres or 0.1 million ha; Table 1$)$. This heavy reliance on public ownership is consistent across all states except Maine, where working forest easements on private conserved lands (1.8 million acres or 0.7 million ha) exceed public holdings of conserved lands (1.2 million acres or 0.5 million ha). Elsewhere, the percentage of total statewide conserved lands in public ownership ranges from a low of 63\% in Vermont to a high of 82\% in New York (Table 1).

For purposes of protecting species habitat values and ecosystem processes, larger, contiguous conserved lands are generally preferred to smaller, more scattered areas. In the Northeast, there are several very large, contiguous protected areas, including four that are greater than a half million acres each (Figure 2). These include 2.3 million acres (930,777 ha) associated with the Adirondack Park in upstate New York, 753,000 acres (304,728 ha) centered on the White Mountain National Forest in New Hampshire, 878,000 acres (355,314 ha) in northern Maine that includes a complex of working forest easements and public land in and around Baxter State Park, and an additional 597,000 acres (241,597 ha) located nearby that combines primarily working forest interspersed with some public reserves (Figure 2).

Despite the impressive large blocks that dominate northern portions of the region, the median conserved parcel size in the Northeast is several orders of magnitude smaller than those large examples. Furthermore, there is a clear dichotomy between the sizes of contiguous blocks in the southern portion compared with those in the north. For example, the states of Connecticut, Rhode Island, and Massachusetts contain no contiguous blocks of conservation lands in the size range of 10,000 acres (4,047 ha) or greater; instead, these states are dominated by numerous much smaller conservation parcels. This trend reflects the availability and low cost of larger tracts of land typically found in the sparsely populated northern areas. In numerical terms, Massachusetts has by far the greatest number of protected contiguous blocks $(13,523)$, while Connecticut has the second highest 
total, with 9,950 contiguous blocks.

The relative cost of land, in combination with individual states' level of funding of public bond investments, also affects conservation land configuration. For example, the cost of conserving an acre in the time period 1998 to 2005 varied from \$245 to \$504/acre in northern New England (Vermont, New Hampshire, and Maine), to \$2,180 to \$3,945/acre in southern New England (Rhode Island, Connecticut, and Massachusetts, Figure 3). As a result, conservation efforts in Massachusetts during this time period were able to conserve roughly the same amount of land as efforts in Vermont, but at three times the cost. Protection of these conserved lands through fee or easement was fueled in part by substantial public bond investments that ranged, over the 8-year period, from \$1.27 billion in New York, to \$48.5 million in Rhode Island. Normalized for population differences, those investments represented per capita public expenses ranging from roughly \$46 in Rhode Island, to \$115 in Connecticut and Vermont.

\section{Representation of Natural Systems}

Conserved lands are distributed across six broad eco-regions (Figure 2) that have been recognized as large, contiguous areas containing characteristic and distinct assemblages of species and natural communities. These eco-regions range from coastal areas (North Atlantic Coast) and lowlands along the St. Lawrence River and Lake Ontario (St. Lawrence/Champlain Valley and the Great Lakes), to inland piedmont and plateau areas (Lower New England/Northern Piedmont and the High Alleghany Plateau), and include boreal-influenced areas (Northern Appalachian/Acadian) to the north. As implied by Figure 2, conserved lands are well represented within all six eco-regions. Although conservation lands within each state contain a mix of major land cover types, protected lands across the region are dominated by forest vegetation, with 61 to $90 \%$ forest cover in each of the northeastern states. 
Freshwater wetlands represent 4\% (New Hampshire) to 20\% (Rhode Island) of conservation lands in each state, whereas agricultural fields and cultivated lands represent as much as 10\% (Vermont) to as little as 1\% (Maine) of conserved lands. For the entire Northeast, forest and wetland cover types are a larger fraction and agricultural land uses are a smaller fraction of conservation lands as compared with the relative abundances of these cover types in the overall land area of the northeastern states (Figure 4).

Ecological land units (ELUs) provide a valuable assessment tool that combines three abiotic indicators of landscape diversity — landform, geology, and elevation—into a single classification metric. Landscape structure diversity has been suggested as an ideal predictor for biological diversity and fostering ecosystem resilience, particularly when there is uncertainty about species' distribution dynamics that may result from climate change. In numerical terms, 87 to 93\% of the ELUs in each of the northeastern states are represented within the conserved lands network. Thus, although some ELUs are overrepresented in relation to their areal abundance (e.g., high elevation zones, where both alpine biodiversity and recreational opportunities are prized), conservation lands generally contain a broad cross section of the landscape diversity reflected in ELU categories.

\section{Representation of Socioeconomic Systems}

In addition to ecological values, conserved lands provide ecosystem services and direct human benefits such as groundwater recharge, flood control, and recreational opportunities. For example, protected agricultural lands provide not only open space and wildlife habitat, but employment and income opportunities as well. Similarly, many protected forestlands remain part of the working landscape. Of the roughly 14.2 million acres (5.7 million ha) protected in the region, 3.3 million acres (1.3 million ha), or 23\%, are presumed to be working forests. Public access to parks and recreational opportunities 
is a common objective of conservation projects at many scales, including community land trusts, city and county open space plans, and state and regional initiatives. Over 3 million acres (1.2 million ha), or 25\% of the total acres protected in New England, are within 15 miles $(24 \mathrm{~km})$ of town centers with populations of 10,000 or greater. These areas tend to be small, with an average and median size of 316 and 110 acres (126 ha and 44ha), respectively.

\section{Conserved Lands in Relation to Future Development Pressures}

While nearly $20 \%$ of the seven-state region has been protected, development pressures are expected to continue across the Northeast. In fact, a 2010 study led by Harvard University found that for the first time in more than a century, the region is losing forest cover across all six New England states. Moreover, unlike past declines in the 1800s that resulted from agricultural conversion, the report described today's losses as "hard” deforestation, where forests and agricultural lands are converted to other uses, such as development, that are unlikely to be reversed in human timescales.

Research by the U.S. Forest Service predicts that private forests throughout the Northeast are likely to experience increased development pressures in coming decades (Figure 5). Growth is expected north and south of the greater Boston Metro region, along southern coastal Maine, and in and around Burlington, Vermont. As shown in Figure 5, much of the anticipated growth pressure will likely occur in less rural parts of the region that are distant from the large tracts of protected conservation lands.

\section{Lessons Learned and Challenges}

The significant gains in conservation realized in the Northeast over the past century are noteworthy in 
two respects. First, they have been achieved across a largely privately owned landscape experiencing rapid population growth and associated development. Second, the approaches and tools employed (e.g., public/private partnerships and less-than-fee ownership strategies) themselves have steadily evolved to address both changing landscapes as well as the public values that drive land conservation. This innovative adaptability and resilience offer promise for conservation efforts worldwide.

We take three key lessons from the Northeast that can provide guidance to other regions in the United States and abroad. First, successes in landscape conservation are due in part to the region's strong conservation ethic and sense-of-place. Second, in regions such as the Northeast that are dominated by private ownership, conservation initiatives must utilize a wide and adaptable set of conservation tools that can adjust to the complex partnerships, regulatory structures, and incentive systems that govern private landscapes. The wide- spread use of working forest easements is just one example of a hybrid approach that protects lands from development while maintaining private ownership and resource production. Third and paradoxically, a key driver of conservation is development, which both creates public demands for conservation and generates the resources—-both political and fiscal— to enact protection. In the Northeast, high and increasing population densities in southern New England and New York have stimulated public interest in land protection throughout the region and not just in areas threatened by development.

Despite these gains, significant challenges remain. For example, conservationists have historically measured success by the number of acres protected. This practice, combined with a growing array of conservation interests, goals, and tools, has fueled an opportunistic approach to land conservation where the collective sum of protected parcels may fall short of larger landscape-level conservation goals. Indeed, while the emergence of landscape ecology as a scientific discipline increasingly guides protection 
efforts, these same principles have identified significant gaps in coverage. Moreover, easements, as one example, might appear to protect a large swath of undeveloped land, but because of rights reserved by the landowner, might not provide the anticipated level of protection of ecological or other public values.

Going forward, the scientific community and ENGOs should strategically build on past gains, aggregate dispersed parcels into larger connected units and networks, and foster compatible land uses in critical areas—especially those adjacent to protected core lands and along important ecological corridors. Important advances include aggregation efforts such as those found within the Wildlands and Woodlands vision, and efforts to foster "adaptive capacity" by protecting landscape heterogeneity and connectivity to foster species migration in response to climate change. Similarly, conservation interests should anticipate future development trends in order to forge proactive-rather than reactive - conservation strategies. Ongoing fiscal pressures will continue to force public- and privatesector organizations to be ever more frugal and deliberate in their efforts, protecting only the lands deemed to have the highest conservation values. Indeed, the League of Conservation Voters estimates that under the 2013 budget sequester alone, state conservation and environmental programs will be cut by \$200 million. Moreover, as ENGOs struggle with membership declines, sluggish revenues, and ongoing management costs, reduced access to capital reinforces the need to measure conservation success as more than the sum total of acres- to ensure that the most appropriate, not the least expensive and available lands, are protected. Conservation organizations need to continue to be creative and take advantage of unique opportunities in market conditions, as they did during the wide- spread forestland ownership divestiture in northern New England in the 2000s. Also important are the long-term costs of monitoring and managing conserved lands—-both for easement and title holders, and for local communities affected by reduced property tax bases. For example, under the guidance of the Land Trust Alliance's accreditation program, land trusts are encouraged to endow $75-100 \%$ of projected long-term stewardship expenses. Future efforts should consider improving the efficiencies of conservation 
monitoring, such as easement registries that improve the transparency of conserved lands.

Finally, the political climate in recent decades has trended toward reduced regulation, leading all levels of government to relax policies to protect the public interest for fear of adversely affecting private property rights. Indeed, many of the new conservation strategies described herein are seller or donor driven and have been developed in lieu of regulatory reforms to protect public values on private lands. This approach, while useful, risks assigning new property rights to private parties, or paying private interests to provide environmental services that otherwise could be, or perhaps already are, required under law. For example, as forests are increasingly valued for carbon storage, is it the landowner's responsibility to maintain carbon stocks, or is this something for which landowners are to be compensated by the public? In short, just as we cannot afford to purchase all lands deemed worthy of protection, we must also not forget the state's long-standing role in protecting public health, safety and welfare. A balance of conservation investment and sensible land-use regulation is required to ensure the long-term sustainability of both human and natural systems. 
References and Notes

G. Godbey, G. DeJong, V. Sasidharan, and C. Yarnal, “The Northeastern United States in the Next Two Decades_-Implications for the Northeast Region of the National Park Service” (Washington DC: National Park Service, 2001).

R. J. Lilieholm, L. C. Irland, and J. M. Hagan, “Changing Socio-Economic Conditions for Private Woodland Protection,” in S. C. Trombulak and R. F. Baldwin, eds., Landscape-Scale Conservation Planning (New York, NY: Springer-Verlag, 2010), pp. 67-98.

J. R. Swanton, The Indian Tribes of North America (Washington, DC: Smithsonian Institution Press, 1952).

Foster, D.R., B.M. Donahue, D.B. Kittredge, K.F. Lambert, M.L. Hunter, B.R. Hall, L.C. Irland, R.J. Lilieholm, D.A. Orwig, A.W. D’Amato, E.A. Colburn, J.R. Thompson, J.N. Levitt, A.M. Ellison, W.S. Keeton, J.D. Aber, C.V. Cogbill, C.T. Driscoll, T.J. Fahey, and C.M. Hart. 2010. Wildlands and Woodlands: A Vision for the New England Landscape. Harvard Forest, dist. by Harvard University Press, Cambridge, Massachusetts. 36pp.

J. N. Levitt, Conservation Capital in the Americas: Exemplary Conservation Finance Initiatives (Cambridge, MA: Lincoln Institute of Land Policy, 2010).

V. W. Brooks, The Flowering of New England, 1815-1865 (New York, NY: E. P. Dutton, 1936).

S. Fairfax, L. Gwin, M. King, R. Leigh and L. Watt, Buying Nature:The Limits of Land Acquisition as a Conservation Strategy, 1780-2004 (Cambridge, Massachusetts: MIT Press, 2005).

For a history of the federal charitable income tax deduction for conservation easement donations, see Nancy A. McLaughlin, Internal Revenue Code Section 170(h): National Perpetuity Standards for Federally Subsidized Conservation Easements, Part 1, The Standards, 45 Real Prop. Tr. \& Est. L.J. 473 (2010). 
Land Trust Alliance, “2010 National Land Trust Census Report: A Look at Voluntary Conservation in America” (2011). Available from: http://www. landtrustalliance.org/land-trusts/land-trust-census.

Trust for Public Land, “Conservation Almanac” (2010). Available from: http://www.conservationalmanac. org/secure.

E. Nelson, M. Uwasu, and S. Polasky, "Voting on Open Space: What Explains the Appearance and Support of Municipal-level Open Space Conservation Referenda in the United States?,” Ecological Economics 62, no. 3-4 (2007): 580-593.

W. J. Ginn, Investing in Nature: Case Studies of Land Conservation in Collaboration with Business (Washington, DC: Island Press, 2005).

Maine State Planning Office, “Maine Conservation Easement Registry” (2010), http://www.maine.gov/spo/specialprojects/conservationeasement.

C. R. Margules and R. L. Pressey, “Systematic Conservation Planning,” Nature 405 (2000): 243-253.

R. L. Pressey, C. J. Humphries, C. R. Margules, R. I. Vane-Wright, and P. H. Williams, “Beyond Opportunism: Key Principles for Systematic Reserve Selection,” Trends in Ecology and Evolution 8, no. 4 (1993): 124-128.

C. S. Cronan, R. J. Lilieholm, J. Tremblay, and T. Glidden, “A Retrospective Assessment of Land Conservation Patterns in Maine based on Spatial Analysis of Ecological and Socio-economic Indicators,” Environmental Management 45, no. 5 (2010): 1076-1095.

Conservation Almanac 2011. Trust for Public Land (TPL), “Conservation Almanac” (2011). Available on the Internet at www.conservationalmanac.org/.

The Nature Conservancy, “TNC Ecoregions and Divisions Map” (1999). Available from http://gis.tnc.org/ data/MapbookWebsite/map_page.php?map_id=9.

C. Ferree, M. G. Anderson, and A. Olivero, “Draft Supplementary Metadata for Systems Raster Dataset,” Unpublished report to The Nature Conservancy (2006). A copy can be requested from 
Charles Ferree, Landscape Ecologist, Eastern North America Division, The Nature Conservancy, Boston, MA, cferree@tnc.org.

P. Beier and B. Brost, "Use of Land Facets to Plan for Climate Change: Conserving the Arenas, Not the Actors,” Conservation Biology 24, no. 3 (2010): 701-710.

Includes areas that have the GAP status 3 designation, indicating that they are protected from development but subject to extractive uses, and are under an easement. See P. J. Crist, B.

Thompson, T. C. Edwards, C. J. Homer, and S. D. Bassett, Mapping and Categorizing Land Stewardship. A Handbook for Conducting Gap Analysis (1998). Available from http://gapanalysis.nbii.gov.

U.S. Geological Service, Geographic Names Information System (GNIS) spatial dataset (2011). Available from http://geonames.usgs.gov/.

The Nature Conservancy, “Secured Areas Database, Northeast Region” (2009), http://conserveonline.org/workspaces/ecs/napaj/nap.

S. M. Stein, R. E. McRoberts, R. J. Alig, M. D. Nelson, D. M. Theobald, M. Eley, M. Dechter, and M. Carr, “Forests on the Edge: Housing Development on America's Private Forests,” USDA Forest Service General Technical Report PNW-GTR-636 (Washington, DC: 2005).

D. Dobbs and R. Ober, The Northern Forest (White River Junction, VT: Chelsea Green Publishing, 1995).

R. W. Judd, Common Lands, Common People: The Origins of Conservation in Northern New England (Cambridge, MA: Harvard University Press, 1997).

A. Walker and R. Ryan, "Place Attachment and Landscape Preservation in Rural New England: A Maine Case Study,” Landscape and Urban Planning 86, no. 2 (2008): 141-152.

A. M. Merenlender, L. Huntsinger, G. Guthey, and S. K. Fairfax, "Land Trusts and Conservation Easements: Who Is Conserving What for Whom?,” Conservation Biology 18 (2004): 65-75. 
A. R. Rissman, L. Lozier, T. Comendant, P. Kareiva, J. M. Kiesecker, M. R. Shaw, and A. M. Merenlender, “Conservation Easements: Biodiversity Protection and Private Use,” Conservation Biology 21, no. 3 (2007): 709-718.

A. M. Merenlender, D. Newburn, S. E. Reed, and A. Rissman, “The Importance of Incorporating Threat for Efficient Targeting and Evaluation of Conservation Investments. (Response to Underwood et al. 'Evaluating Conservation Spending for Species Return: A Retrospective Analysis in California.'),” Conservation Letters 2 (2009): 240-241.

K. J. Willis and S. A. Bhagwat, “Biodiversity and Climate Change,” Science 326 (2009): 807.

S. R. Meyer, M. L. Johnson, and R. J. Lilieholm, "Landscape Conservation in the United States: Evolution and Innovation Across the Urban-Rural Interface,” in W. Zipper, D.N. Laband, and B.G. Lockaby, eds., Urban-Rural Interfaces: Linking People and Nature (American Society of Agronomy, Crop Science Society of America, and Soil Science Society of America, Madison, Wisconsin, 2012), pp. 225-258.

J. M. Kiesecker, T. Comendant, T. Grandmason, E. Gray, C. Hall, R. Hilsenbeck, P. Kareiva, L. Lozier, P. Naehu, A. Rissman, M. R. Shaw, and M. Zankel, “Conservation Easements in Context: A Quantitative Analysis of Their Use by The Nature Conservancy,” Frontiers in Ecology and the Environment 5 (2005): 125-130.

E. T. Freyfogle, The Land We Share: Private Property and the Common Good, (Washington, DC: Island Press, 2003).

H. R. Richmond, "Metropolitan Land-Use Reform: The Promise and Challenge of Majority Consensus,” in B. Katz, ed., Reflections on Regionalism (Washington, DC: Brookings Institution, 2000), pp. 9-40. 
Acknowledgements

Robert J. Lilieholm is the E. L. Giddings Associate Professor of Forest Policy in the School of Forest Resources at the University of Maine in Orono, Maine. Spencer R. Meyer is an associate research scientist in the Center for Research on Sustainable Forests at the University of Maine in Orono, Maine. Michelle L. Johnson is a graduate research assistant in the School of Forest Resources at the University of Maine in Orono, Maine. Christopher S. Cronan is a professor in the School of Biology and Ecology at the University of Maine in Orono, Maine.

This research was supported by National Science Foundation award EPS-0904155 to Maine EPSCoR Sustainability Solutions Initiative at the University of Maine, and McIntire-Stennis grant number MEOM-7-00510-13 from the USDA National Institute of Food and Agriculture. Additional support was provided by the Maine Agricultural and Forest Experiment Station (Publication No. 3323), and the Center for Research on Sustainable Forests. 
Photographs

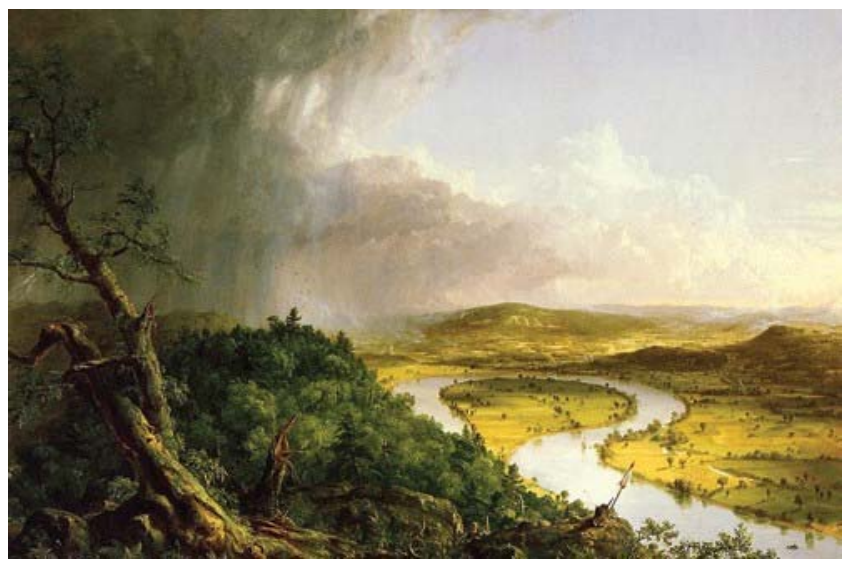

The Oxbow, painted by Thomas Cole in 1836, depicts the view from Mount Holyoke, Northampton, Massachusetts, after a thunderstorm

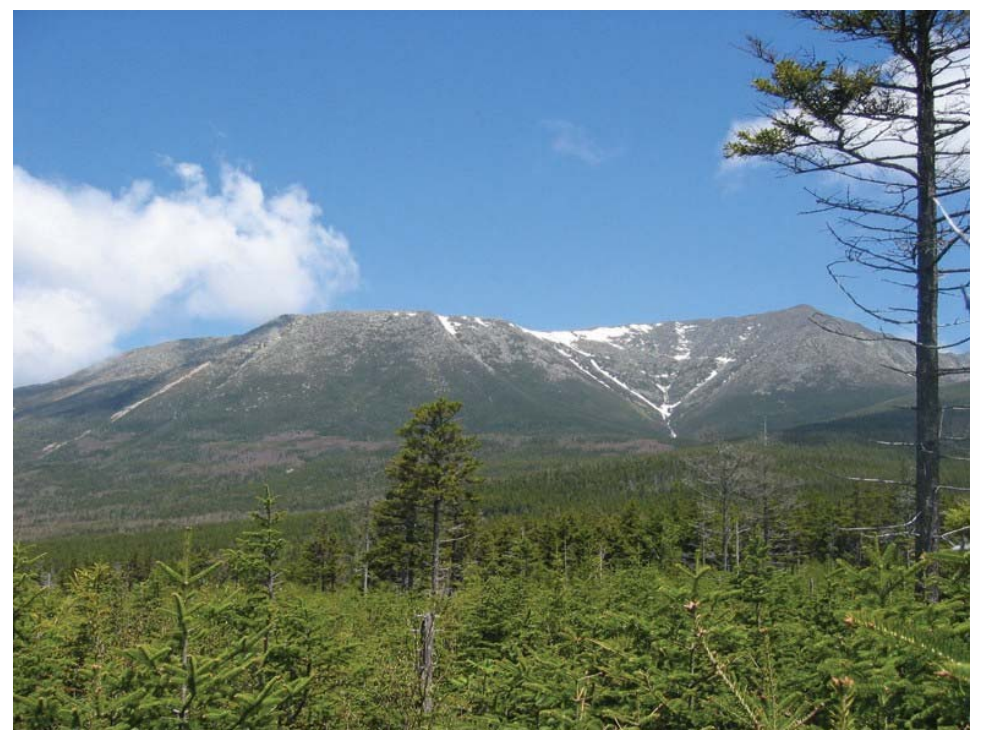

Baxter State Park

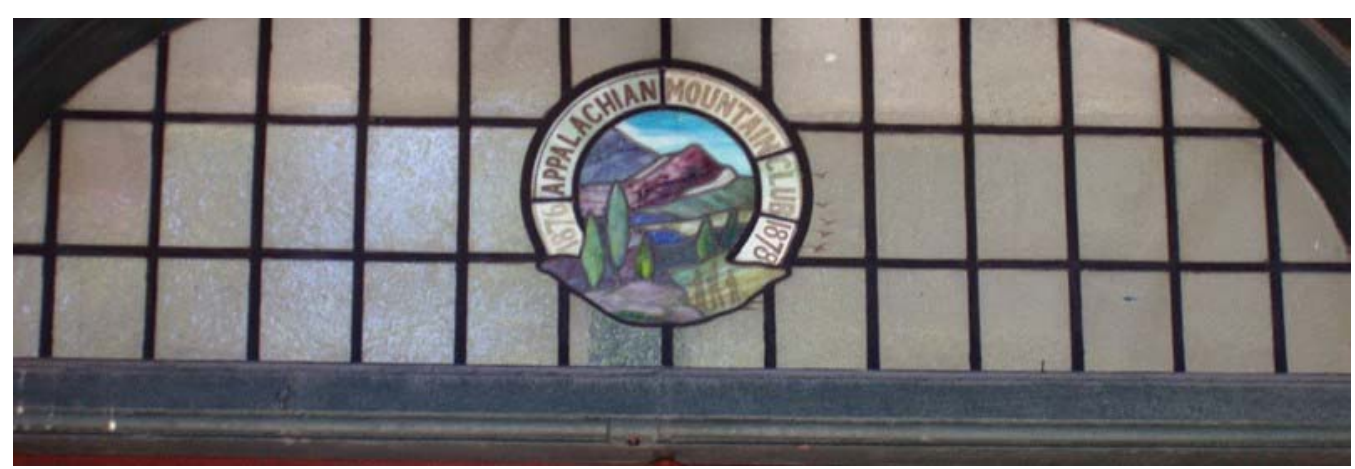

The Appalachian Mountain Club, the nation's oldest recreation and conservation organization, is just one of the many groups purchasing former industrial timberland to manage for recreation, conservation, and timber. (Wikimedia Commons/Daderot) 


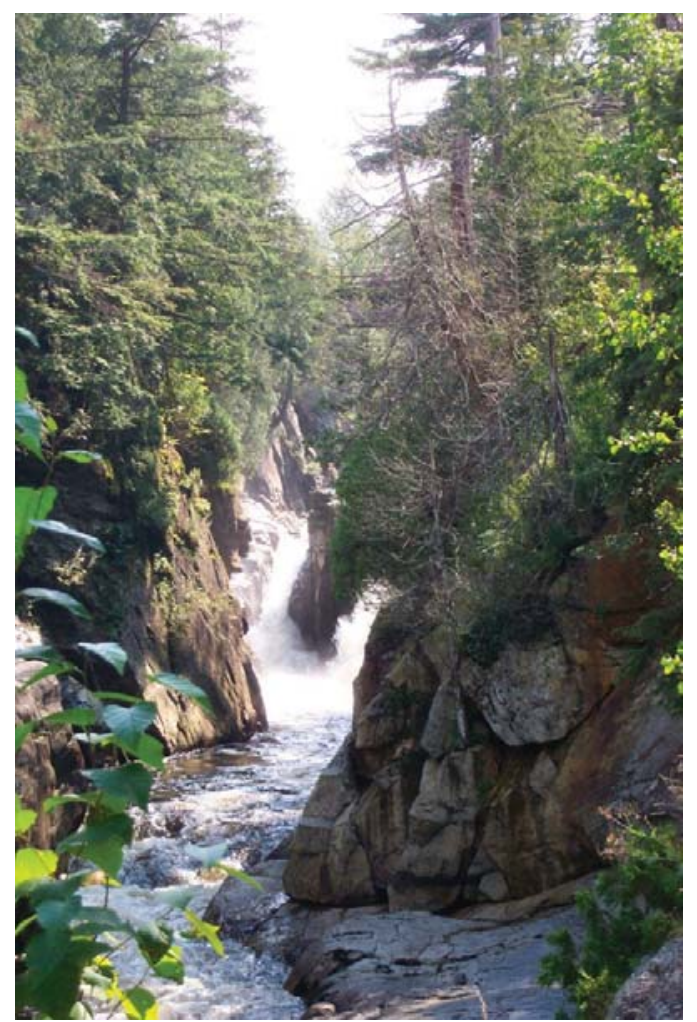

Waterfall in Keen Valley, Adirondacks, NY. Wikimedia Commons/Jarekt

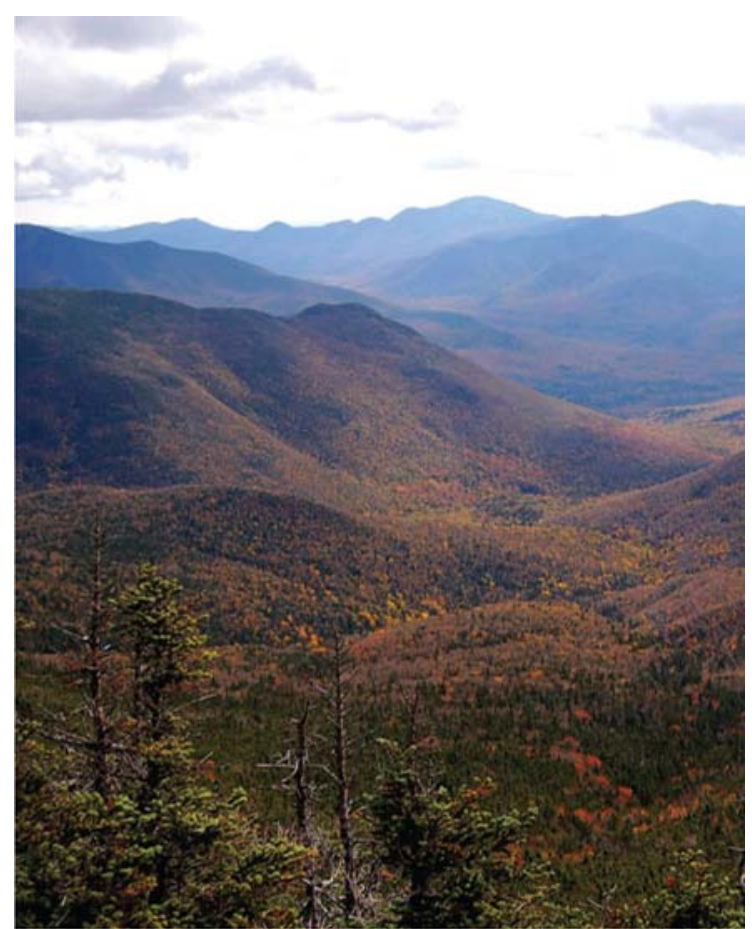

Wikimedia Commons/Charlie DeTar

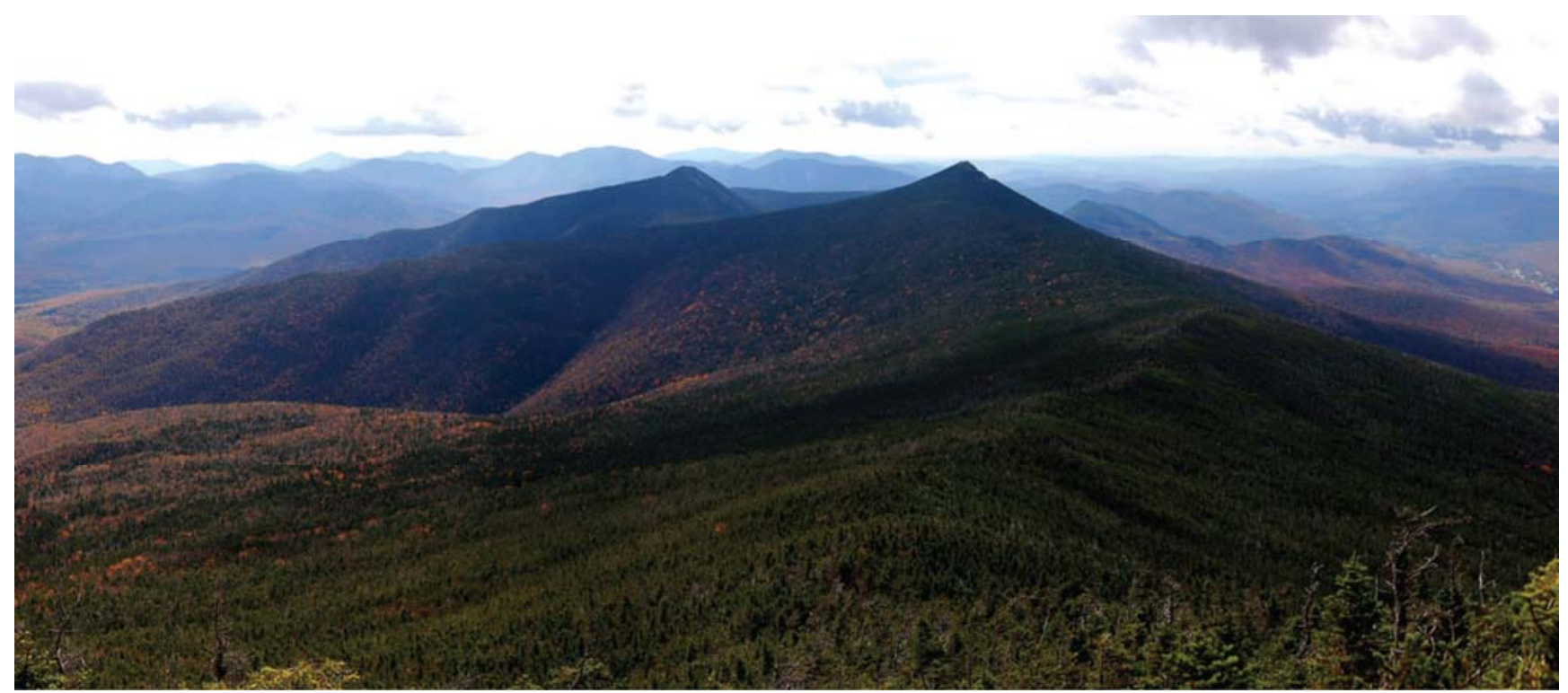

Mt. Liberty, Mt. Flume, parts of the Pemigewasset Wilderness, and parts of Franconia Notch State Park in the White Mountains. 
Figures

Figure 1: Long-term cumulative trend in the aggregate area of conserved lands within the three states of Maine, New Hampshire, and Vermont in the northeastern United States. Historical milestones are indicated.

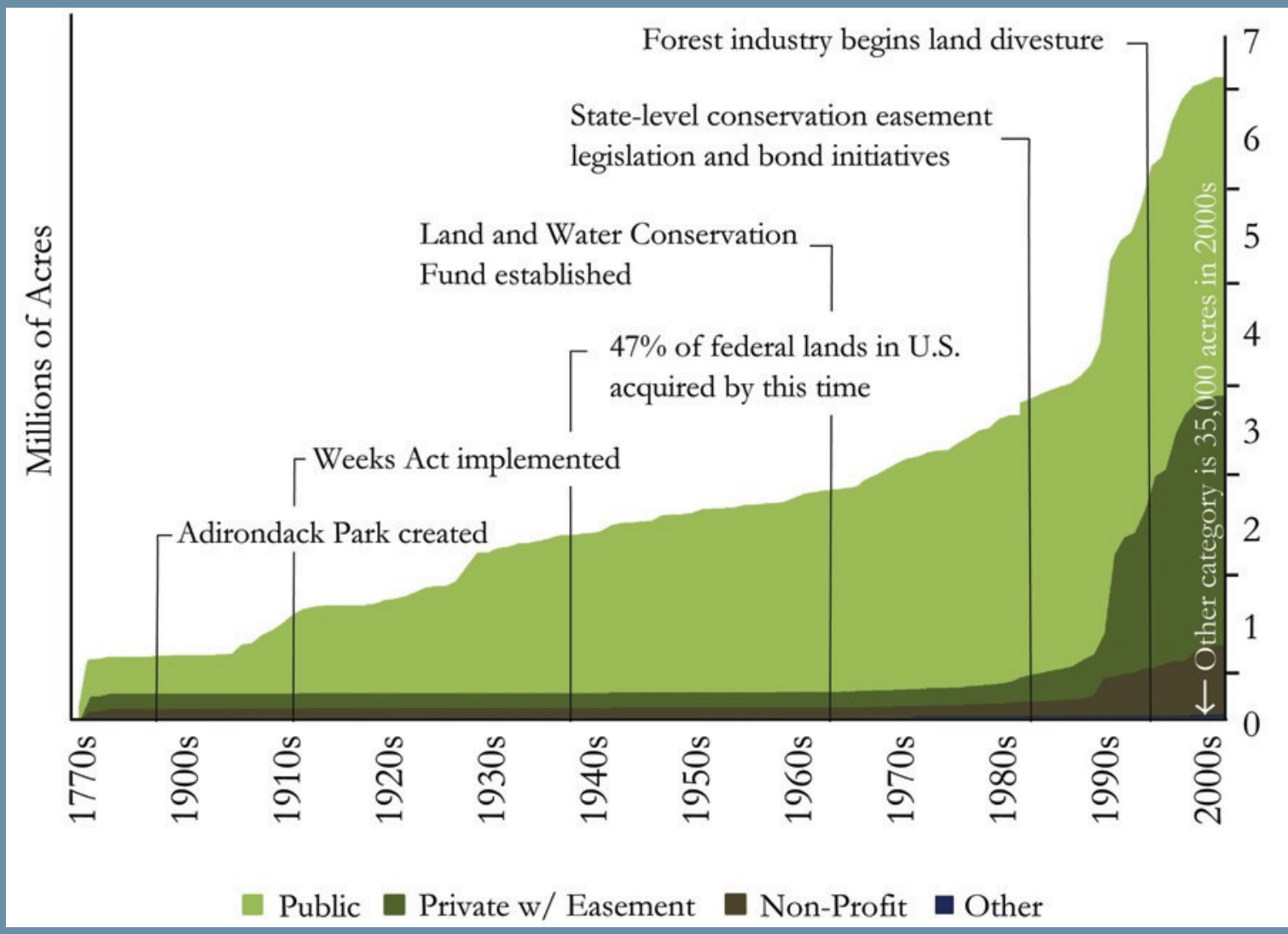




\begin{tabular}{|c|c|c|c|c|c|c|c|}
\hline State & $\begin{array}{l}\text { Public } \\
\text { Ownership }\end{array}$ & $\begin{array}{l}\text { Private w/ } \\
\text { Easement }\end{array}$ & $\begin{array}{l}\text { Non-Profit } \\
\text { Ownership }\end{array}$ & Other & Total Acres & Unconserved & $\begin{array}{l}\text { Percent of } \\
\text { State }\end{array}$ \\
\hline New York & $4,703,103$ & 767,065 & 198,550 & 99,089 & $5,767,807$ & $29,147,238$ & $16.5 \%$ \\
\hline New Hampshire & $1,126,171$ & 410,158 & 157,622 & 24,423 & $1,718,374$ & $4,264,276$ & $28.7 \%$ \\
\hline Vermont & 865,668 & 430,742 & 77,779 & 2,009 & $1,376,198$ & $4,778,254$ & $22.4 \%$ \\
\hline Rhode Island & 96,966 & 10,188 & 21,828 & 20,726 & 149,708 & 839,017 & $15.1 \%$ \\
\hline Total & $9,279,119$ & $3,511,329$ & $1,187,872$ & 245,177 & $14,223,497$ & $66,764,581$ & $17.6 \%$ \\
\hline \multicolumn{8}{|c|}{ Source: The Nature Conservancy 2009 and 2011} \\
\hline
\end{tabular}


Figure 2: Locations of public and private conserved lands (green) in relation to six major eco-regions delineated by The Nature Conservancy (1995) in the northeastern United States.

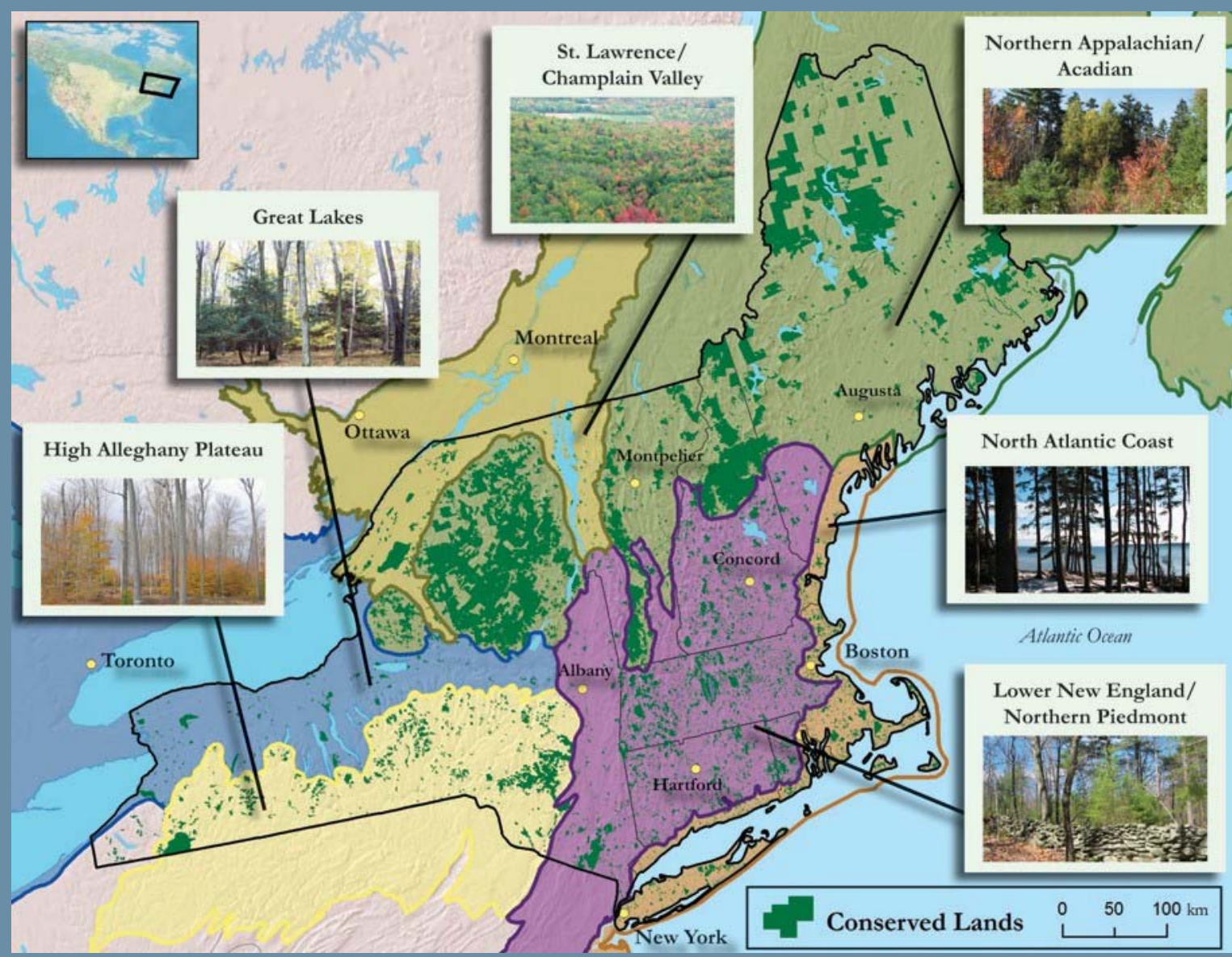


Figure 3: Total acres conserved and cost per acre by state during an 8-year period, 1998 to 2005, based on data from the Conservation Almanac.

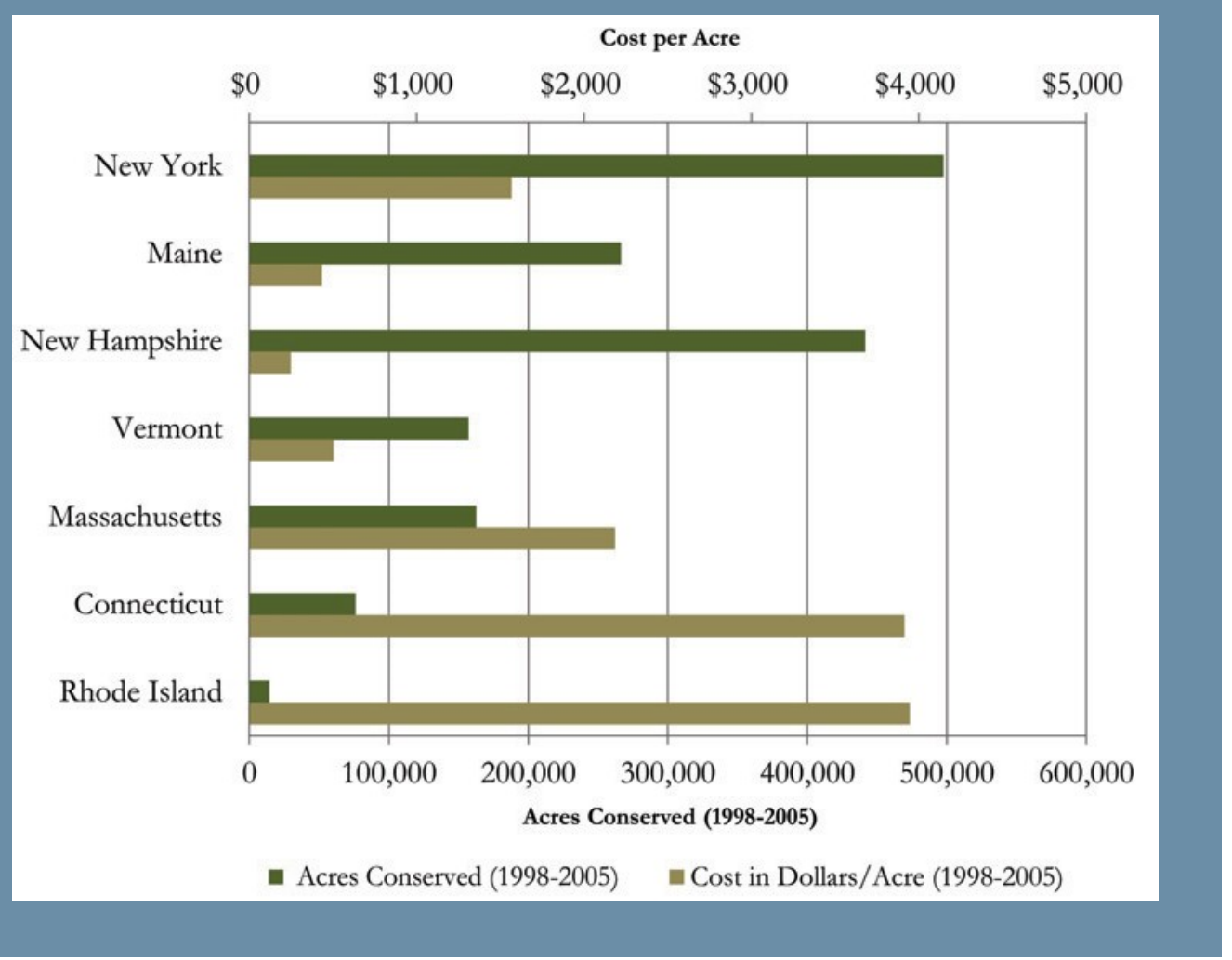


Figure 4: Land cover proportions on state conservation lands compared with the entire land base in each state. Each bar expresses the over- or underrepresentation of a given land cover type on conservation lands (cal- culated by subtracting the statewide percentage of a land cover type from the percentage of that land cover type on all combined conservation lands in the state). Forests include mixed, hardwood, conifer, and scrub/shrub (regeneration) cover types; farming includes agricultural lands and fields.

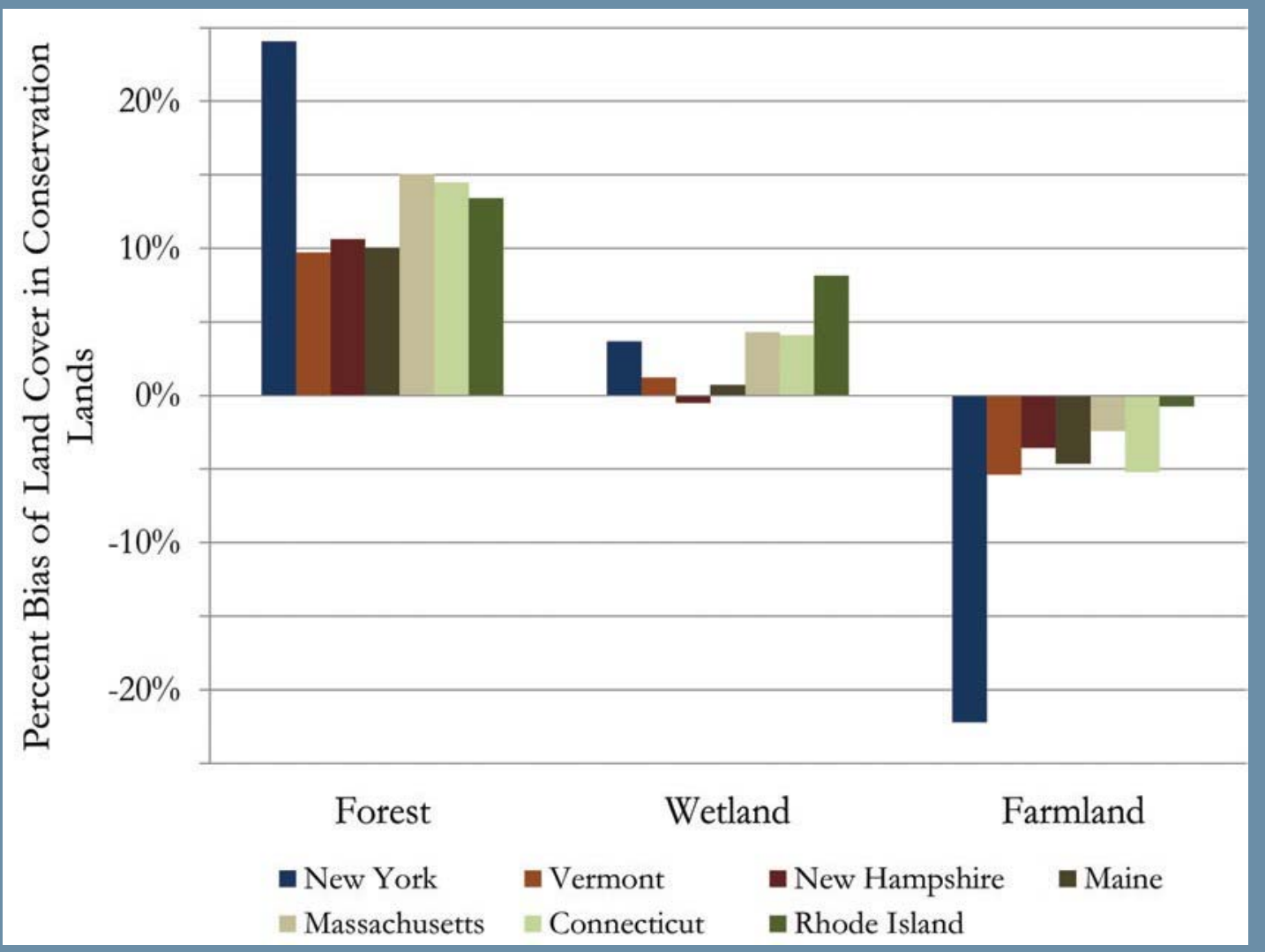


Figure 5: Projected intensity of development pressure on forests of the Northeast during the time period from 2000 to 2030.

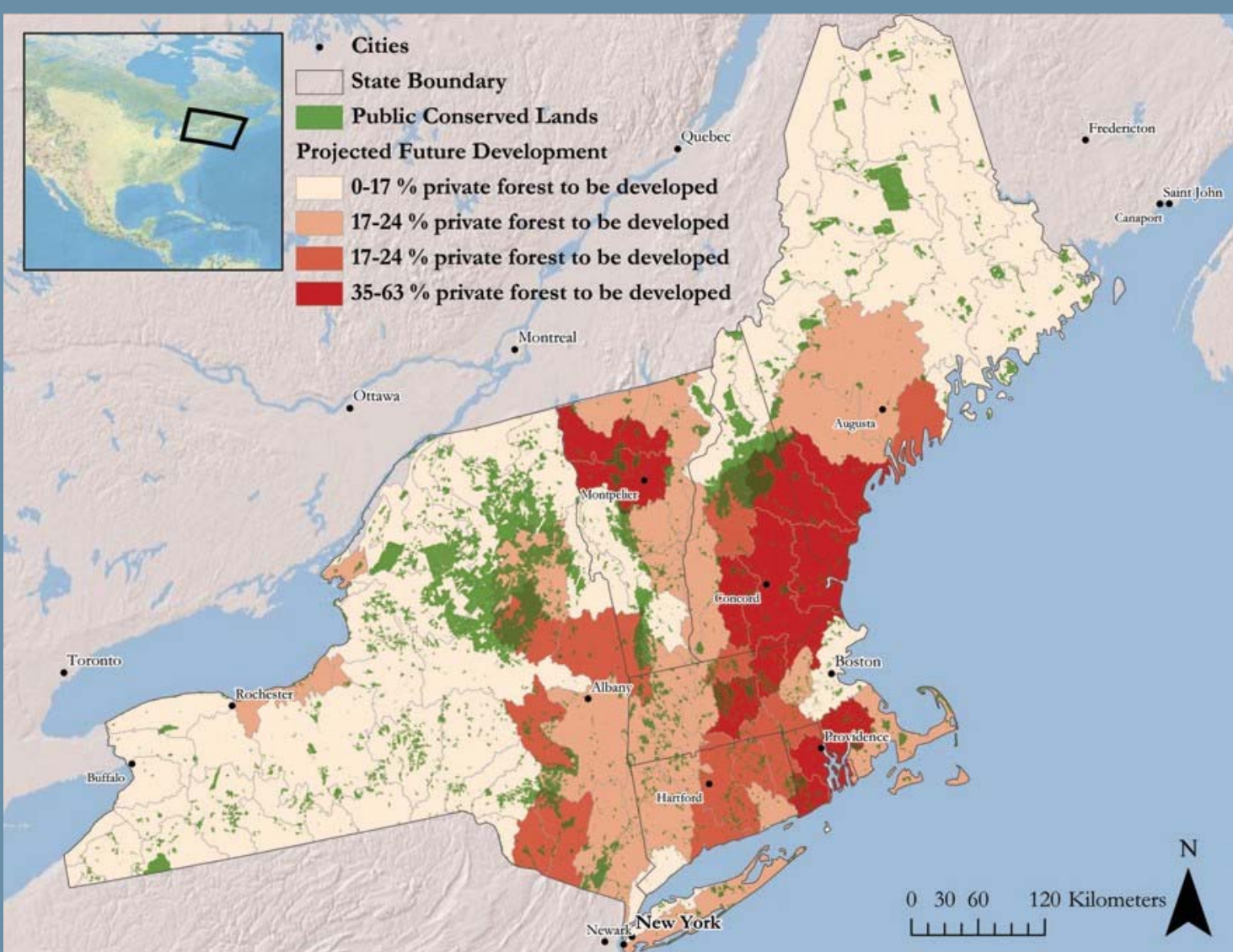

